Огляди літератури, оригінальні дослідження, погляд на проблему, випадок з практики, короткі повідомлення удК 576.314.6/.7:591.747:616.5-001.1

DOI 10.11603/1811-2471.2020.v.i4.11761

\title{
ВИГОТОВЛЕННЯ АЦЕЛЮЛЯРНОГО ДЕРМАЛЬНОГО МАТРИКСУ ЗІ ШКІРИ СВИНІ: МОРФОЛОГІЧИЙ АНАЛІЗ
}

\section{ОІ. С. Кулянда, Л. Я. ФедонюК, А. І. Довгалюк, С. Б. Крамар, О. О. Кулянда}

Тернопільський національний медичний університет імені І. Я. Горбачевського моз України

РЕзюМЕ. Перспективним напрямком у лікуванні дефектів шкіри різної етіології є використання децелюляризованої (ацелюлярної) шкіри свині.

Мета - розробити методику виготовлення ацелюлярного дермального матриксу з дерми шкіри свині зі збереженням нативної структури.

Матеріал і методи. Процес виготовлення ацелюлярного дермального матриксу полягав у поєднанні фізичних і хімічних впливів на дерму. Забір дерми завтовшки 1,0-1,3 мм проводили у свиней віком до 1 року 3 ділянки спини та, частково, з бокових ділянок тулуба. Попередньо за допомогою дерматома із відповідних ділянок знімали шар шкіри товщиною 0,3-0,4мм, який піддавали фізичній і хімічній обробці. Досягнення максимальної ацелюлярності дермального матриксу здійснювали покроково, цей процес включав 4 етапи обробки шкіри: 1 - процес заморожування - розморожування; 2 - дегідратація гліцерином; 3 - осмотичний стрес; 4 - вимивання детергентом решток клітин.

Для оцінки ефективності протоколу децелюляризації проводили морфологічний аналіз дерми за допомогою світлової мікроскопії.

Результати. Гістологічний аналіз дерми шкіри свині після циклів заморожування - розморожування виявив, що колагеновий каркас дермального матриксу, отриманий у результаті першого етапу децелюляризації, зберігає свою структурну організацію.

Другий етап децелюляризації виявив зменшення кількості клітин фібробластичного ряду. При цьому сполучнотканинні елементи, які представлені різноспрямованими пучками колагенових волокон, зберігали свою структурну організацію.

Третій етап децелюляризації виявив лізис клітин фібробластичного ряду, які у вигляді базофільно забарвлених елементів у незначній кількості локалізувались у дермі.

У результаті промивки ліофілізованої шкіри неіонним детергентом додецилсульфатом натрію виявлено повну відсутність клітин фібробластичного ряду, епідермоцитів у складі волосяних фолікулів, ендотеліоцитів у стінці кровоносних судин, що свідчить про ефективність вказаного реагента у видаленні залишків продуктів розпаду клітин.

Висновок. Запропонований протокол децелюляризації дерми шкіри свині $\epsilon$ ефективним для видалення ядерних та клітинних структур із дерми. Конкретні протоколи можуть бути змінені шляхом збільшення різниці температур або зміни кількості циклів заморожування - розморожування.

КлючовІ СлОВА: шкіра свині; дерма; ацелюлярний дермальний матрикс; морфологія.

Вступ. Перспективним напрямком у лікуванні дефектів шкіри різної етіології є використання децелюляризованої (ацелюлярної) шкіри свині. Основними перевагами такого біологічного матеріалу є склад і структура свинячої дерми, що максимально наближені до дерми хворого [1]. Різні дослідження показують, що замінники шкіри можуть покращувати якість лікування ранових дефектів та функціональні результати. Вони $\epsilon$ корисним інструментом у пластичній і реконструктивній хірургії [2-6].

На сьогодні запропоновані фізичні та хімічні методи децелюляризації, що дозволяють зберігати структуру та властивості ксеногенних трансплантатів [7, 8]. Проведені дослідження показали, що безклітинний дермальний матрикс підтримує проникнення фібробластів, неоваскуляризацію та епітелізацію за відсутності імунної відповіді реципієнта [9]. Також показано, що косметичні й функціональні результати після застосування ксеногенних дермальних трансплантатів для лікування дефектів шкіри значно перевершують результати після аутодермопластики перфорованим клаптем, а також сприяють швидшому загоєнню донорських ран у зв'язку з тим, що вимагають більш тонких аутодермотрансплантатів $[10,11]$.

Втім, методи децелюляризації мають, як правило, протилежні ефекти: вкрай агресивне видалення імуногенних компонентів може зруйнувати структуру і склад тканин, тоді як більш щадні методики можуть зберегти імуногенність тканини. Тобто, способи отримання замінників шкіри не мають універсального носія клітинних структур, який би володів біосумісністю, створював оптимальне мікросередовище для регенерації рани, мав би абсорбційну здатність щодо ранового ексудату, запобігав проникненню і розвитку мікроорганізмів, був би проникним для водяної пари і повітря, не висушував дна рани, був еластичним, моделював би поверхню зі складним рельєфом. 
Огляди літератури, оригінальні дослідження, погляд на проблему, випадок з практики, короткі повідомлення

Мета - розробити методику виготовлення ацелюлярного дермального матриксу (АДМ) з дерми шкіри свині зі збереженням нативної структури.

Матеріал і методи дослідження. Процес виготовлення АДМ полягав у поєднанні фізичних і хімічних впливів на дерму. Забір дерми завтовшки 1,0-1,3 мм проводився у свиней віком до 1 року з ділянки спини та, частково, з бокових ділянок тулуба. Попередньо за допомогою дерматома із відповідних ділянок знімали шар шкіри товщиною 0,3-0,4 мм, який піддавали фізичній і хімічній обробці. Досягнення максимальної ацелюлярності дермального матриксу здійснювали покроково, цей процес включав 4 етапи обробки шкіри: 1 - процес заморожування - розморожування; 2 дегідратація гліцерином; 3 - осмотичний стрес; 4 - вимивання детергентом решток клітин. Заморожування проводили в рідкому азоті $\left(-196{ }^{\circ} \mathrm{C}\right)$, розморожування - у воді при температурі $37{ }^{\circ} \mathrm{C}$. Цей цикл повторювали тричі. Далі шкіру тричі обробляли розчином гліцерину, проводили осмотичний стрес шляхом поперемінного занурення дерми в дистильовану воду та в гіпертонічний розчин. Після цього шкіру обробляли 1 М розчином $\mathrm{NaOH}$.

На завершальному етапі залишки продуктів розпаду клітин, білків та інших компонентів позаклітинного матриксу видаляли за допомогою 1 \% додецилсульфату натрію (SDS).

Після цього шкіру піддавали сублімаційному висушуванню.

Для оцінки ефективності протоколу децелюляризації проводили морфологічний аналіз дерми за допомогою світлової мікроскопії. 3 цією метою зразки нативної ( $n=6)$ та децелюляризованої (n=6) дерми фіксували у 10 \% нейтральному формаліні, заливали парафіном. Отримані зрізи завтовшки 5 мкм депарафінізували і фарбували гематоксиліном та еозином (H\&E; Sigma-Aldrich, Inc., St Louis, MO, USA) для виявлення ядерного, клітинного та позаклітинного матеріалів.

Результати й обговорення. За результатами світлооптичної мікроскопії в ліофілізованій дермі свині до початку децелюляризації не виявлено ознак аутолітичних і некробіотичних змін та глибоких порушень її структурної організації (рис. 1).
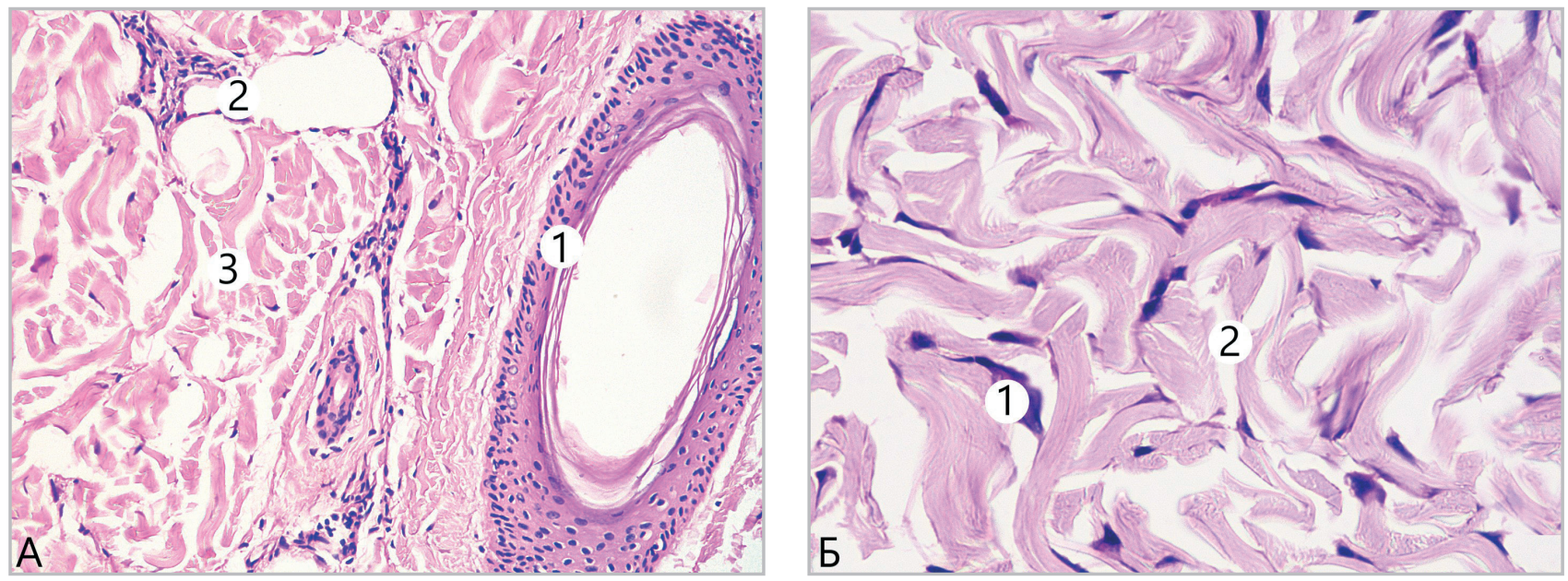

Рис. 1. Гістологічний стан ретикулярного шару ліофілізованої дерми. Забарвлення гематоксиліном та еозином. А: 1 - волосяний фолікул, 2 - судини, 3 - колагенові волокна. х100. Б: 1 - фібробласти, 2 - колагенові волокна. $\times 400$.

У результаті мікроскопічного дослідження ліофілізованої шкіри виявили, що в основній масі клітин добре збережені ядра і цитоплазма фібробластів, а також епідермоцитів у складі волосяного фолікула, і лише у незначній частині клітин наявні пікноз та вакуолізація.

Колагенові волокна дерми в переважній більшості гістологічних препаратів контуровані, утворюють сітку і різноспрямовано локалізовані в сосочковому шарі (рис. 1, Б).

У глибше розміщених частинах дерми (сітчастий шар) відмічається незначний набряк і гомогенізація окремих ділянок колагенових воло- кон, а в окремих випадках - їх фрагментація. Сполучнотканинний каркас також представлений чітко контурованими тонкими еластичними волокнами.

Гістологічний аналіз дерми шкіри свині після циклів заморожування - розморожування виявив, що сітчастий і сосочковий шари дерми утворені волокнистою сполучною тканиною, в якій переважають колагенові волокна. Волокнистий компонент сітчастого шару представлений товстими пучками, що різноспрямовано розташовуються у міжклітинному матриксі та мають оксифільне забарвлення (рис. 2). 
Огляди літератури, оригінальні дослідження, погляд на проблему, випадок з практики, короткі повідомлення

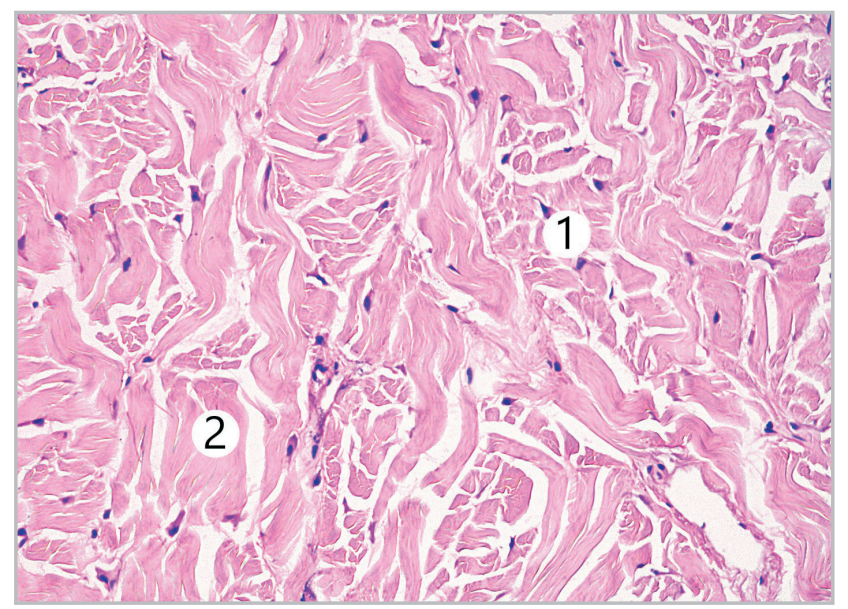

Рис. 2. Мікроскопічний стан ліофілізованої дерми після циклів заморожування - розморожування: 1 фібробласти, 2 - колагенові волокна. Забарвлення гематоксиліном та еозином. ×200.

Клітинний склад представлений переважно фібробластами, ядра яких при фарбуванні гематоксиліном та еозином мають базофільне забарвлення.

Отримані результати показують, що колагеновий каркас дермального матриксу, отриманий у результаті першого етапу децелюляризації, зберігає свою структурну організацію.

Другий етап децелюляризації - дегідратація багатоатомним спиртом гліцерином - привів до зменшення кількості клітин фібробластичного ряду (рис. 3). При цьому сполучнотканинні елементи, які представлені різноспрямованими пучками колагенових волокон, зберігають свою структурну організацію, що підтверджується даними світлової мікроскопії.

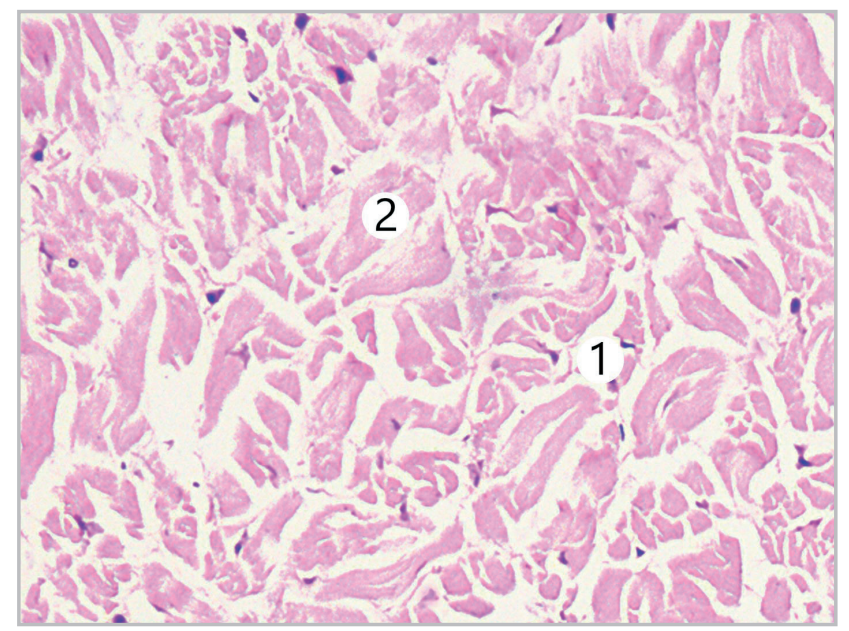

Рис. 3. Гістологічні зміни ліофілізованої дерми після дегідратації гліцерином: 1 - пошкоджені фібробласти, 2 - колагенові волокна. Забарвлення гематоксиліном та еозином. $\times 200$.
Третій етап децелюляризації (осмотичний стрес) виявив лізис клітин фібробластичного ряду, оскільки гіпотонічні розчини легко викликають розчинення клітинного матеріалу за допомогою простих осмотичних ефектів з мінімальними змінами в молекулах матриці та їі архітектурі [12], гіпертонічний фізіологічний розчин дисоціює ДНК 3 білків [13]. Дані, отримані в результаті світлової мікроскопії, виявили незначну кількість базофільно забарвлених елементів у складі дерми, що можна розцінювати як залишки структурних компонентів клітин (рис. 4).

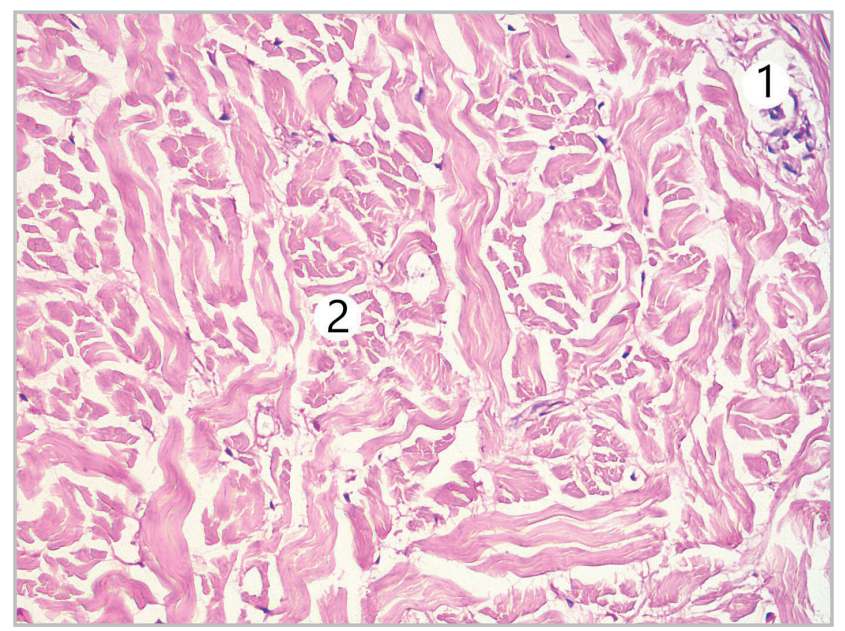

Рис. 4. Мікроскопічний стан ліофілізованої дерми після осмотичного стресу: 1 - залишки клітинного матеріалу, 2 - колагенові волокна. Забарвлення гематоксиліном та еозином. $\times 100$.

Завершальний етап дослідження передбачав промивання ліофілізованої шкіри неіонним детергентом додецилсульфатом натрію (SDS). Це сприяло видаленню залишків продуктів розпаду клітин, що свідчить про ефективність цього реагента.

Дані світлової мікроскопії демонструють повну відсутність клітин фібробластичного ряду, епідермоцитів у складі волосяних фолікулів, ендотеліоцитів і гладких міоцитів у стінці кровоносних судин (рис. 5).

Відомо, що цикли заморожування - розморожування не впливають на вміст колагену і глюкозаміногліканів (ГАГ), а також на механічну міцність біологічного матеріалу [14]. Проте 88 \% ДНК у клітинах залишається без зміни після такого фізичного впливу [14]. Отже, даний фізичний вплив на ліофілізовану шкіру можна розглядати як пусковий механізм пошкоджувальних впливів на клітинні структури дерми.

На етапі децелюляризації дерми спирти, зокрема гліцерин, сприяють структурній реорганізації клітин шляхом їх дегідратації та лізування 


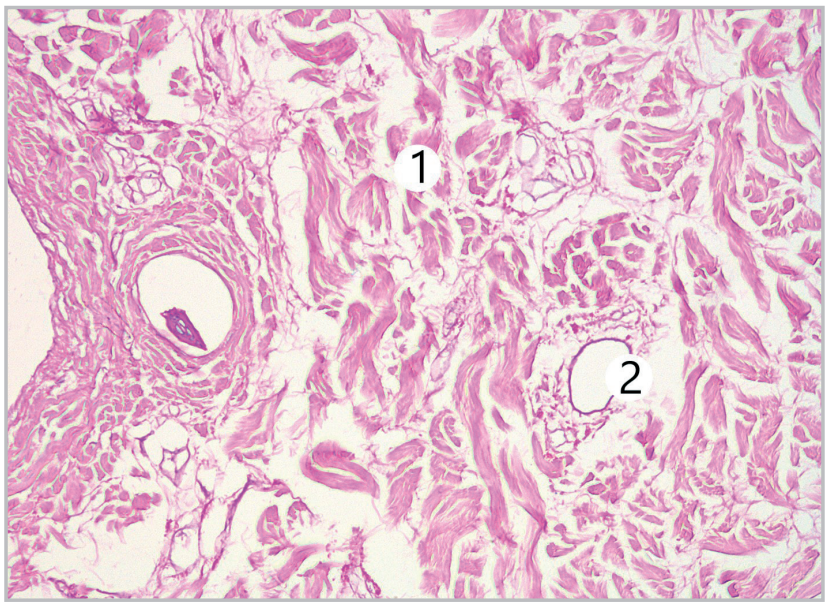

Рис. 5. Гістологічний стан ретикулярного шару ліофілізованої дерми після промивання додецилсульфатом натрію (SDS): 1 - колагеновий каркас, 2 - стінка судини. Забарвлення гематоксиліном та еозином. ×100.

[15]. Також спирти розчинять фосфоліпіди, які входять до складу клітинних мембран [16]. Проте, слід звертати увагу на негативний вплив спиртів на тканини через їх здатність осаджувати білки, а також на пошкодження, яких вони завдають ультраструктурі позаклітинного матриксу $[17,18]$.

Для отримання максимального осмотичного ефекту (третій етап децюляризації) тканини занурюють почергово в гіпер- і гіпотонічні розчини впродовж кількох циклів, що сприяє вимиванню залишків клітин з тканини після лізису.

Етап промивання ліофілізованої шкіри неіонним детергентом додецилсульфатом натрію (SDS) виявився ефективним для повного видалення клітинного матеріалу з дерми, оскільки це привело до солюбілізації клітинних мембран і повного їх вимивання з тканин. 3більшення експозиції та кон- центрації в протоколі децелюляризації за допомогою SDS приводить також до повного видалення клітинних ядер [19]. Видалення білків позаклітинного матриксу та ДНК за допомогою детергентів зростає з часом експозиції [20] і змінюється залежно від органної субодиниці, типу тканини та донорського віку [19]. SDS $\epsilon$, як правило, більш ефективним для видалення клітинних залишків з тканини, порівняно з іншими детергентами, але одночасно й більш руйнівним для екстрацелюлярного матриксу $[21,22]$. Тому потрібно обережно та точно підбирати концентрацію SDS та експозицію для кожної тканини.

Видалення клітинного матеріалу із дерми шкіри свині як потенційного покриття ранової поверхні значно знижує антигенні властивості матеріалу, забезпечуючи його постійне приживлення до ранового ложа з проростанням судин і поступовим заповненням власними клітинами реципієнта. 36ереження структури колагенової матриці сприяє ангіогенезу і міграції клітин [23]. У перспективі децелюляризовані дермальні матрикси розглядають як один із основних варіантів каркасу для створення біоінженерного аутологічного еквівалента шкіри.

Висновок. Запропонований протокол децелюляризації дерми шкіри свині $\epsilon$ ефективним для видалення ядерних та клітинних структур із дерми. Конкретні протоколи можуть бути змінені шляхом збільшення різниці температур або зміни кількості циклів заморожування - розморожування.

Перспективи подальших досліджень. Планується дослідити ступінь цитотоксичності та тканинну сумісність дерми шкіри свині, виготовленої за даним протоколом, для оцінки ефективності та безпечності in vivo даного децелюляризованого каркасу при використанні для лікування пацієнтів.

\section{ЛІТЕРАТУРА}

1. Comparative histology and immunohistochemistry of porcine versus human skin / S. Debeer, J. B. Le Luduec, D. Kaiserlian [et al.] // Eur. J. Dermatol. - 2013. - Vol. 23 (4). P. 456-466.

2. Chong skin tissue engineering advances in severe burns: review and therapeutic applications / A. W. Chua, Y. C. Khoo, B. K. Tan [et al.] // Burns Trauma. -2016. - Vol. 4. P. 3.

3. Tracy L. E. Extracellular matrix and dermal fibroblast function in the healing wound / L. E. Tracy, R. A. Minasian, E. J. Caterson // Adv. Wound Care (New Rochelle). 2016. - Vol. 5 (3). - P. 119-136.

4. Future prospects for scaffolding methods and biomaterials in skin tissue engineering: a review / A. A. Chaudhari, K. Vig, D. R. Baganizi [et al.] // Int. J. Mol. Sci. - 2016. Vol. 17 (12). - P. 1974.

5. Biomaterials for skin substitutes / M. Sheikholeslam, M. E. E. Wright, M. G. Jeschke, S. Amini-Nik // Adv. Healthc. Mater. - 2018. - Vol. 7 (5). - P. 1700897.

6. Progress in developing decellularized bioscaffolds for enhancing skin construction / H. Cui, Y. Chai, Y. Yu // J.Biomed. Mater. Res. A.-2019.-Vol. 107 (8).-P.1849-1859.

7. Hrebikova H. Chemical decellularization: a promising approach for preparation of extracellular matrix / H. Hrebikova, D. Diaz, J. Mokry // Biomed. Pap. Med. Fac. Univ. Palacky Olomouc Czech. Repub. -2015. - Vol. 159 (1). P. 12-17.

8. Crapo P. M. An overview of tissue and whole organ decellularization processes / P. M. Crapo, T. W. Gilbert, S. F. Badylak // Biomaterials. - 2011. - Vol. 32 (12). - P. 3233-3243.

9. Preservation, sterilization and de-epithelialization of human amniotic membrane for use in ocular surface re- 
Огляди літератури, оригінальні дослідження, погляд на проблему, випадок з практики, короткі повідомлення construction / A. K. Riau, R. W. Beuerman, L. S. Lim, J. S. Mehta // Biomaterials. - 2010. - Vol. 31 (2). - P. 216-225.

10. The role of the extracellular matrix components in cutaneous wound healing / P. Olczyk, L. Mencner, K. Komosinska-Vassev // BioMed. Res. Int. - 2014. - Vol. 2014. P. 747584.

11. Volk S. W. Interactions of the extracellular matrix and progenitor cells in cutaneous wound healing / S. W. Volk, S. A. Iqbal, A. Bayat // Adv. Would Care. - 2013. Vol. 2 (6). - P. 261-272.

12. Xu C. C. Biodegradable, acellular xenogeneic scaffold for regeneration of the vocal fold lamina propria / C. C. Xu, R. W. Chan, N. A. Tirunagari // Tissue Eng. - 2007. Vol. 13 (3). - P. 551-566.

13. Cox $B$. Tissue subcellular fractionation and protein extraction for use in mass-spectrometry-based proteomics / B. Cox, A. Emili // Nat. Protoc. - 2006. - Vol. 1 (4). P. 1872-1878.

14. Decellularization of fibroblast cell sheets for natural extracellular matrix scaffold preparation / Q. Xing, K. Yates, M. Tahtinen [et al.] // Tissue Engineering-Part C Methods. - 2015. - Vol. 21 (1). - P. 77-87.

15. Development of acellular dermis from porcine skin using periodic pressurized technique / I. Prasertsung, S. Kanokpanont, T. Bunaprasert [et al.] // J. Biomed. Mater. Res. B. Appl. Biomater. - 2008. - Vol. 85 (1). - P. 210-219.

16. Inhibition of cusp and aortic wall calcification in ethanol- and aluminum-treated bioprosthetic heart valves in sheep: background, mechanisms, and synergism / R. J. Levy, N. Vyavahare, M. Ogle [et al.] // J. Heart Valve Dis. - 2003. - Vol. 12 (2). - P. 209-216.

\section{REFERENCES}

1. Debeer, S., Le Luduec, J.B., Kaiserlian, D., Laurent, P., Nicolas, J.F., Dubois, B., \& Kanitakis, J. (2013). Comparative histology and immunohistochemistry of porcine versus human skin. Eur. J. Dermatol., 23 (4), 456-466.

2. Chua, A.W., Khoo, Y.C., Tan, B.K., Tan, K.C., Foo, C.L., \& Chong, S.J. (2016). Skin tissue engineering advances in severe burns: review and therapeutic applications. Burns Trauma, 4, 3. DOI: 10.1186/s41038-016-0027-y.

3. Tracy, L.E., Minasian, R.A., \& Caterson, E.J. (2016). Extracellular matrix and dermal fibroblast function in the healing wound. Adv. Wound Care (New Rochelle), 5, 119136.

4. Chaudhari, A.A., Vig, K., Baganizi, D.R., Sahu, R., Dixit, S., Dennis, V., ..., \& Pillai, S.R. (2016). Future prospects for scaffolding methods and biomaterials in skin tissue engineering: a review. Int. J. Mol. Sci., 17 (12), 1974.

5. Sheikholeslam, M., Wright, M.E.E., Jeschke, M.G., Amini-Nik, S. (2018). Biomaterials for skin substitutes. Adv. Healthc. Mater., 7 (5), 1700897.

6. Cui, H., Chai, Y., \& Yu, Y. (2019). Progress in developing decellularized bioscaffolds for enhancing skin construction. J. Biomed. Mater. Res. A, 107 (8), 1849-1859.

7. Hrebikova, H., Diaz, D., \& Mokry, J. (2015). Chemical decellularization: a promising approach for preparation of extracellular matrix. Biomed. Pap. Med. Fac. Univ. Palacky Olomouc Czech. Repub., 159 (1), 12-17.

17. Clinical comparison of the Tutoplast allograft and autologous patellar tendon (bone-patellar tendon-bone) for the reconstruction of the anterior cruciate ligament: 2- and 6-year results / O. Gorschewsky, A. Klakow, K. Riechert [et al.] // Am. J. Sports Med. - 2005. - Vol. 33 (8). P. 1202-1209.

18. Quantitative analysis of biochemical characteristics of bone-patellar tendon-bone allografts / O. Gorschewsky, A. Puetz, K. Riechert [et al.] // Biomed. Mater. Eng. 2005. - Vol. 15 (6). - P. 403-411.

19. Decellularized rhesus monkey kidney as a threedimensional scaffold for renal tissue engineering / K. H. Nakayama, C. A. Batchelder, C. I. Lee, A. F. Tarantal // Tissue Eng. Part A. - 2010. - Vol. 16 (7). - P. 2207-2216.

20. Development of a porcine bladder acellular matrix with well-preserved extracellular bioactive factors for tissue engineering / B. Yang, Y. Zhang, L. Zhou [et al.] // Tissue Eng. Part C Methods. - 2010. - Vol. 16 (5). - P. 1201-1211.

21. Histological evaluation and biomechanical characterisation of an acellular porcine cornea scaffold / L. Du, X. Wu, K. Pang, Y. Yang // Br. J. Ophthalmol. - 2010. Vol. 5 3). - P. 410-414.

22. The use of high-hydrostatic pressure treatment to decellularize blood vessels / S. Funamoto, K. Nam, T. Kimura [et al.] // Biomaterials. - 2010. - Vol. 31 (13). P. 3590-3595.

23. Preservation, sterilization and de-epithelialization of human amniotic membrane for use in ocular surface reconstruction / A. K. Riau, R. W. Beuerman, L. S. Lim, J. S. Mehta // Biomaterials. - 2010. - Vol. 31 (2). P. 216-225.

8. Crapo, P.M., Gilbert, T.W., \& Badylak, S.F. (2011). An overview of tissue and whole organ decellularization processes. Biomaterials, 32 (12), 3233-3243.

9. Riau, A.K., Beuerman, R.W., Lim, L.S., \& Mehta, J.S. (2010). Preservation, sterilization and de-epithelialization of human amniotic membrane for use in ocular surface reconstruction. Biomaterials, 31 (2), 216-225.

10. Olczyk, P., Mencner, L., \& Komosinska-Vassev, K. (2014). The role of the extracellular matrix components in cutaneous wound healing. BioMed. Res. Int., 2014, 747584.

11. Volk, S.W., Iqbal, S.A., \& Bayat, A. (2013). Interactions of the extracellular matrix and progenitor cells in cutaneous wound healing. Adv. Would Care, 2 (6), 261-272.

12. Xu, C.C., Chan, R.W., \& Tirunagari, N.A. (2007). Biodegradable, acellular xenogeneic scaffold for regeneration of the vocal fold lamina propria. Tissue Eng.,13 (3), 551-566.

13. Cox, B., \& Emili, A. (2006). Tissue subcellular fractionation and protein extraction for use in mass-spectrometry-based proteomics. Nat. Protoc., 1 (4), 1872-1878.

14. Xing, Q., Yates, K., Tahtinen, M., Shearier, E., Qian, Z., \& Zhao, F. (2015). Decellularization of fibroblast cell sheets for natural extracellular matrix scaffold preparation. Tissue Engineering-Part C Methods., 21 (1), 77-87. DOI: 10.1089/ten.tec.2013.0666.

15. Prasertsung, I., Kanokpanont, S., Bunaprasert, T., Thanakit, V., \& Damrongsakkul, S. (2008). Development of 
Огляди літератури, оригінальні дослідження, погляд на проблему, випадок з практики, короткі повідомлення acellular dermis from porcine skin using periodic pressurized technique. J. Biomed. Mater. Res. B. Appl. Biomater., 85 (1), 210-219.

16. Levy, R.J., Vyavahare, N., Ogle, M., Ashworth, P., Bianco, R., \& Schoen, F.J. (2003). Inhibition of cusp and aortic wall calcification in ethanol- and aluminum-treated bioprosthetic heart valves in sheep: background, mechanisms, and synergism. J. Heart Valve Dis., 12 (2), 209-216.

17. Gorschewsky, O., Klakow, A., Riechert, K., Pitzl, M., \& Becker, R. (2005). Clinical comparison of the Tutoplast allograft and autologous patellar tendon (bone-patellar tendonbone) for the reconstruction of the anterior cruciate ligament: 2- and 6-year results. Am. J. Sports Med., 33 (8), 1202-1209.

18. Gorschewsky, O., Puetz, A., Riechert, K., Klakow, A., \& Becker, R. (2005). Quantitative analysis of biochemical characteristics of bone-patellar tendon-bone allografts. Biomed. Mater. Eng., 15 (6), 403-411.

19. Nakayama, K.H., Batchelder, C.A., Lee, C.I., \& Tarantal, A.F. (2010). Decellularized rhesus monkey kidney as a

three-dimensional scaffold for renal tissue engineering. Tissue Eng. Part A., 16 (7), 2207-2216.

20. Yang, B., Zhang, Y., Zhou, L., Sun, Z., Zheng, J., Chen, Y., \& Dai, Y. (2010). Development of a porcine bladder acellular matrix with well-preserved extracellular bioactive factors for tissue engineering. Tissue Eng. Part. C Methods., 16 (5), 1201-1211.

21. Du, L., Wu, X., Pang, K., \& Yang, Y. (2010). Histological evaluation and biomechanical characterisation of an acellular porcine cornea scaffold. Br. J. Ophthalmol., 95 (3), 410-414.

22. Funamoto, S., Nam, K., Kimura, T., Murakoshi, A., Hashimoto, Y., Niwaya K, ..., \& Kishida, A. (2010). The use of high-hydrostatic pressure treatment to decellularize blood vessels. Biomaterials, 31 (13), 3590-3595.

23. Riau, A.K., Beuerman, R.W., Lim, L.S., \& Mehta, J.S. (2010). Preservation, sterilization and de-epithelialization of human amniotic membrane for use in ocular surface reconstruction. Biomaterials, 31 (2), 216-225.

\title{
ИЗГОТОВЛЕНИЕ АЦЕЛЮЛЯРНОГО ДЕРМАЛЬНОГО МАТРИКСА ИЗ КОЖИ СВИНЬИ: МОРФОЛОГИЧЕСКИЙ АНАЛИЗ
}

\author{
ФИ. С. Кулянда, Л. Я. Федонюк, А. И. Довгалюк, С. Б. Крамар, Е. О. Кулянда \\ Тернопольский национальный медицинский университет имени И. Я. Горбачевского МОз Украины
}

РЕзЮМЕ. Перспективным направлением в лечении дефектов кожи различной этиологии является использование децелюляризованной (ацелюлярной) кожи свиньи.

Цель - разработать методику изготовления ацелюлярного дермального матрикса из дермы кожи свиньи с сохранением нативной структуры.

Материал и методы. Процесс изготовления ацелюлярного дермального матрикса заключался в сочетании физических и химических воздействий на дерму. Забор дермы толщиной 1,0-1,3 мм проводили у свиней в возрасте до 1 года с участка спины и, частично, из боковых участков тела. Предварительно с помощью дерматома из соответствующих участков снимали слой кожи толщиной 0,3-0,4 мм, который подвергали физической и химической обработке. Достижение максимальной ацелюлярности дермального матрикса осуществляли пошагово, этот процесс состоял из 4 этапов обработки кожи: 1 - процесс замораживания - размораживания; 2 - дегидратация глицерином; 3 - осмотический стресс; 4 - вымывание детергентом остатков клеток. Для оценки эффективности протокола децелюляризации проводили морфологический анализ дермы с помощью световой микроскопии.

Результаты. Гистологический анализ дермы кожи свиньи после циклов замораживания-размораживания обнаружил, что коллагеновый каркас дермального матрикса, полученный в результате первого этапа децелюляризации, сохраняет свою структурную организацию.

Второй этап децелюляризации обнаружил уменьшение количества клеток фибробластического ряда. При этом соединительнотканные элементы, которые представлены разнонаправленными пучками коллагеновых волокон, сохраняли свою структурную организацию.

Третий этап децелюляризации обнаружил лизис клеток фибробластического ряда, которые в виде базофильно окрашенных элементов в незначительном количестве локализировались в дерме.

В результате промывки лиофилизированной кожи неионным детергентом додецилсульфатом натрия обнаружено полное отсутствие клеток фибробластического ряда, эпидермоцитов в составе волосяных фолликулов, эндотелиоцитов в стенке кровеносных сосудов, что свидетельствует об эффективности данного реагента в удалении остатков продуктов распада клеток.

Выводы. Предложенный протокол децелюляризации дермы кожи свиньи является эффективным по удалению ядерных и клеточных структур из дермы. Конкретные протоколы могут быть изменены путем увеличения разницы температур или изменения количества циклов замораживания - размораживания.

КЛючЕВЫЕ СЛОВА: кожа свиньи; дерма; ацелюлярный дермальный матрикс; морфология. 


\section{@I. S. Kulyanda, L. Ya. Fedoniuk, A. I. Dovgalyuk, S. B. Kramar, O. O. Kulyanda I. Horbachevsky Ternopil National Medical University}

SUMMARY. The main propose on the treatment of skin defects of various etiologies is the use of decelularized (acellular) pig skin.

The aim - to create the method of production an acellular dermal matrix of the dermis of pig's skin while preserving the native structure.

Material and Methods. The process of creating an acellular dermal matrix was a combination of physical and chemical effects on the dermis. Derma (1.0-1.3 mm thick) was taking from the back and partly from the lateral surfaces of the body of the 1 year-old pigs. Previously, a layer of skin $0.3-0.4 \mathrm{~mm}$ thick was removed from the relevant areas with the help of a dermatome. Achieving the maximum acellularization of the dermal matrix was carried out step by step and included 4 stages: 1 - the process of freezing-thawing; 2 - dehydration with glycerin; 3 -osmotic stress; 4 - washing with detergent.

Results and Discussion. Histological analysis of the dermis of pig's skin after freeze-thaw cycles revealed that the collagen skeleton of the dermal matrix, obtained as a result of the first stage of decelularization, has normal structural organization.

The second stage of decelularization revealed a decrease in the number of fibroblasts. The connective tissue elements, which are represented by multidirectional bundles of collagen fibers, retained their structural organization.

The third stage of decelularization revealed the lysis of fibroblastic cells, which as the basophilic stained elements were localized in small quantities in the dermis.

Washing of lyophilized skin with nonionic detergent sodium dodecylsulfate revealed the complete absence of fibroblastic cells, epidermocytes in the hair follicles, endothelial cells in the wall of blood vessels, which indicates the effectiveness of this reagent in removing residual products.

Conclusions. The proposed protocol for deceleralization of the dermis of pig's skin is effective in removing nuclear and cellular structures from the dermis. Specific protocols can be modified by increasing the temperature difference or changing the number of freeze-thaw cycles.

KEY WORDS: pig's skin; derma; acellular dermal matrix; morphology. 